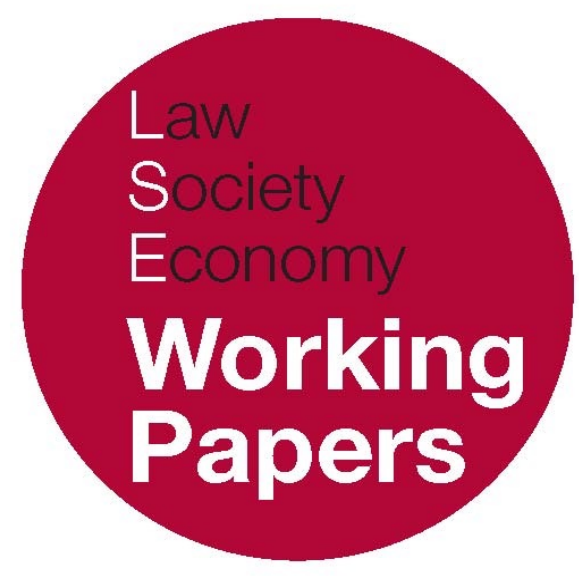

\title{
The Value of Insolvency Safe Harbours
}

\author{
Philipp Paech
}

LSE Law, Society and Economy Working Papers 9/2015

London School of Economics and Political Science

Law Department

This paper can be downloaded without charge from LSE Law, Society and Economy Working Papers at: www.lse.ac.uk/collections/law/wps/wps.htm and the Social Sciences Research Network electronic library at: http://ssrn.com/abstract $=2578521$.

(C) Philipp Paech. Users may download and/or print one copy to facilitate their private study or for non-commercial research. Users may not engage in further distribution of this material or use it for any profit-making activities or any other form of commercial gain. 


\title{
The Value of Insolvency Safe Harbours
}

\author{
Philipp Paech ${ }^{*}$
}

\begin{abstract}
Safe harbour' is shorthand for a bundle of privileges in insolvency which are typically afforded to financial institutions. They are remotely comparable to security interests as they provide a financial institution with a considerably better position as compared to other creditors should one of its counterparties fail or become insolvent. Safe harbours have been introduced widely and continue to be introduced in financial markets. The common rationale for such safe harbours is that the protection against the fallout of the counterparty's insolvency contributes to systemic stability, as the feared 'domino effect' of insolvencies is not triggered from the outset. However, safe harbours are also criticised for accelerating contagion in the financial market in times of crisis and making the market more risky. This paper submits that the more important argument for the existence of safe harbours is liquidity in the financial market. Safe harbour rules do away with a number of legal concepts, notably those attached to traditional security, and thereby allow for an exponentiation of liquidity. Normative decisions of the legislator sanction safe harbours as modern markets could not exist without these high levels of liquidity. To the extent that safe harbours accelerate contagion in terms of crisis, which in principle is a valid argument, specific regulation is well suited to correct this situation, whereas a repeal or significant restriction of the safe harbours would be counterproductive.
\end{abstract}

\footnotetext{
* Assistant Professor, Department of Law, London School of Economics and Political Science. This paper is work in progress. I would like to thank Christos Hadjiemmanuil, Sarah Paterson and Julia Told for their extremely helpful comments on an earlier draft of this article. Any remaining errors are my own.
} 


\section{INTRODUCTION}

In the aftermath of the global financial crisis of 2008, the financial industry was proud to boast that its standard contracts, the so-called 'master agreements', documenting derivative, repo and other types of financial transactions ${ }^{1}$ worth trillions of US dollars in value, ${ }^{2}$ had withstood the destructive pressure resulting from the downfall of Lehman Brothers, one of the biggest players in the market. ${ }^{3}$ This was taken as substantiating the value of the risk mitigation mechanisms included in these agreements. It is probably fair to say that risk mitigation is the most important function of these master agreements. ${ }^{4}$ Their significance is readily illustrated by a comparison with the real estate market. As the real estate market in its present form would not exist without concepts such as mortgage or hypothec, the modern financial market would not exist without master agreements and their built-in risk mitigation mechanisms, notably termination, close-out netting and collateral. That is to say, what is discussed in this article refers to a cornerstone of our modern economies.

1 This article, for ease of reference, generally refers to derivative and sale-and-repurchase ('repo') transactions. In a derivative contract, the obligations of the parties depend on a reference value which typically changes over time, e.g. the market price of a basket of shares. Derivatives are generally (but not necessarily) documented under the master agreement promoted by the International Swaps and Derivates Association (ISDA), which is not publicly available. Repos are functionally akin to a secured loan but different from the legal perspective: an asset is sold against a cash payment and bought back at a later point in time at a slightly different price. Repos are often documented under the Global Master Repurchase Agreement (GMRA) <http://www.icmagroup.org/assets/documents/Legal/GMRA2011/GMRA-2011/GMRA\%202011_2011.04.20_formular.pdf> accessed 10 March 2015. However, safe harbours generally also cover other types of contracts, such as securities lending, dealings in foreign exchange, financial instruments, precious metals, etc., see UNIDROIT, Principles on the Operation of Close-out Netting Provisions (2013), Principle 4 and accompanying commentary $<$ http://www.unidroit.org/instruments/capital-markets/netting $>$ accessed 10 March 2015. There are many different national, regional and international master agreements, see for further examples P Paech, The Need for an International Instrument on the Enforceability of Close-out Netting in General and in the Context of Bank Resolution, (2011) UNIDROIT Study S78c, Doc. 2, 11 http://www.unidroit.org/english/documents/2011/study78c/s-78c-02-e.pdf > accessed 10 March 2015.

2 To provide a fragmentary and regionally limited picture: at the end of June 2014 the world-wide outstanding gross market value of over-the-counter derivatives was about $17.5 \mathrm{tn}$ USD, see Bank for $\begin{array}{lllll}\text { International Settlements (BIS), Derivatives } & \text { Statistics, } & \text { Table } 19\end{array}$ <http://www.bis.org/statistics/derstats.htm> accessed 10 March 2015. On 8 October 2014 the value of total outstanding repo transactions in the USA was 3.88tn USD, see A Copeland and others, 'Lifting the Veil on the U.S. Bilateral Repo Market' < http://libertystreeteconomics.newyorkfed.org/2014/07/liftingthe-veil-on-the-us-bilateral-repo-market.html\#.VP3J6ELd7wx $>$ last accessed on 10 March 2015. At the European end of the repo market, the total value of the repo contracts outstanding on the books of the 65 institutions that participated in the relevant survey was EUR 5.7tn EUR in June 2014, see International Capital Markets Association, 'European Repo Market Survey, Number 27' $<$ http://www.icmagroup.org/Regulatory-Policy-and-Market-Practice/short-term-markets/Repo-

Markets/repo/latest/> last accessed 10 March 2015.

${ }^{3}$ In relation to the fall-out from the (pre-crisis) Enron scandal see ISDA, 'Enron: Corporate Failure, Market Success' paper delivered at the $17^{\text {th }}$ Annual General Meeting, Berlin, 17 April 2002, 10-15 $<$ http://www.isda.org/whatsnew/pdf/EnronFinal4121.pdf> accessed 10 March 2015.

${ }_{4}$ Master agreements provide the general advantages of widely used standard contracts, such as common terminology, compatibility, etc. The ISDA Master Agreement, for instance, further adds provisions on taxation and on multi-branch scenarios. 
In the event of a financial institution's insolvency or similar event, a master agreement limits the credit risk ${ }^{5}$ of its financial counterparties. ${ }^{6}$ Master agreements enable financial counterparties to liquidate entire portfolios of open contracts as soon as the other part fails or otherwise becomes a greater risk. ${ }^{7}$ Prompt liquidation of all derivatives and repo positions leaves the counterparties with a relatively modest amount to pay to or, respectively, claim from the failing institution. Accordingly, their potential loss remains comparably small and they do not incur the risk of watching their contracts becoming entangled in lengthy insolvency proceedings that might be opened over the failing firm.

The laws of most developed financial markets make sure that these - purely contractual - arrangements are enforceable despite the fact that the liquidation arrangements made under master agreements somehow contravene the pari passu principle, ${ }^{8}$ much as in the case of security interests. The insolvency law provisions that guarantee the enforceability of master agreements in the event of insolvency are generally referred to in the context of US bankruptcy law as the 'safe harbour' rules. ${ }^{9}$ In this article, I will use this catchy label also in relation to other jurisdictions, albeit with the caveat that safe harbours and their context differ from one jurisdiction to another, as will be shown below.

The rationale for the privileged treatment arising under insolvency safe harbours appears to be two-fold. The part of the rationale that occupies the less prominent place in the policy debate concerns increased market liquidity through an increased volume of repo and derivatives transactions. Quite comparably to 'traditional' security interests, ${ }^{10}$ safe harbours encourage financial institutions to

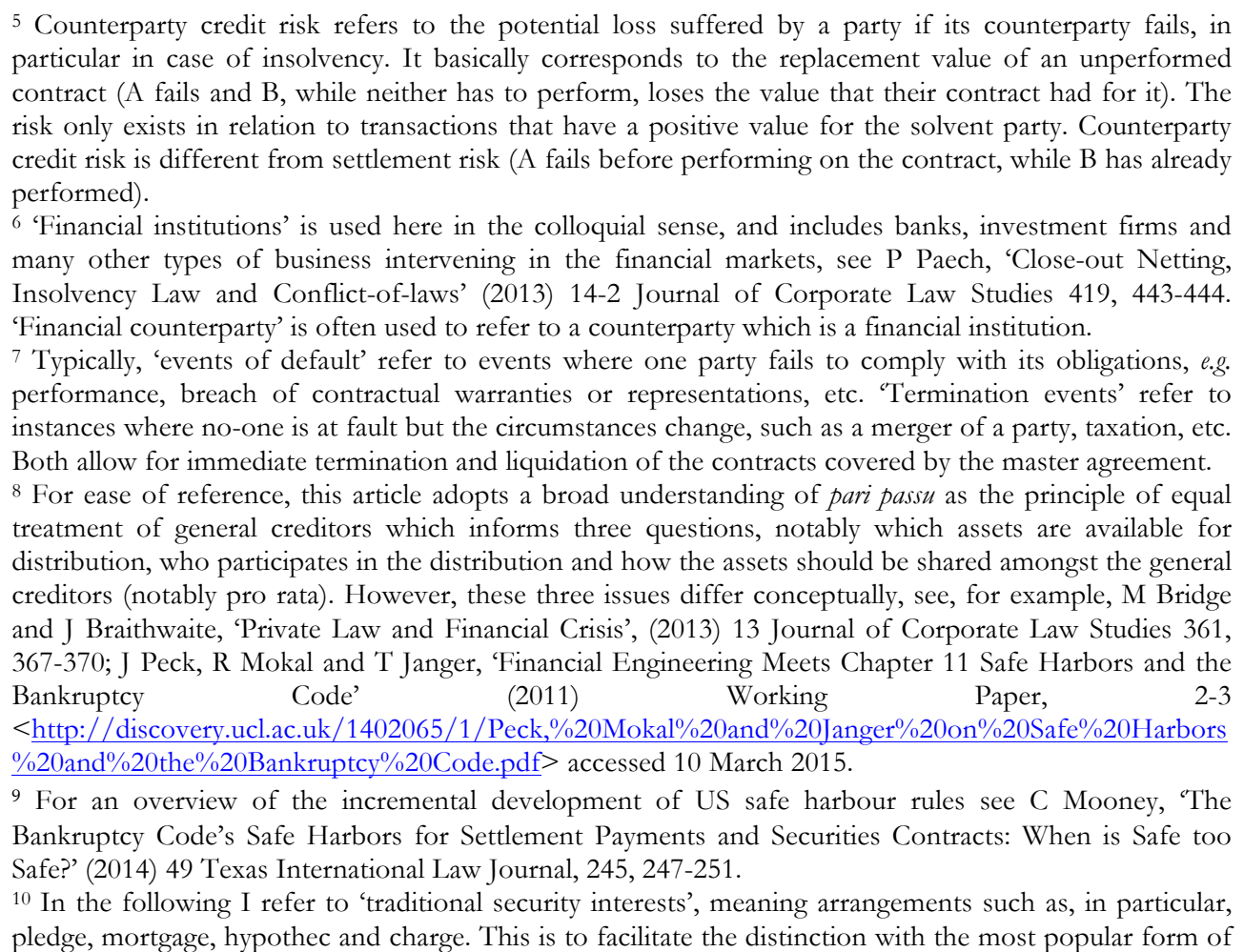


enter into these contracts by considerably reducing the degree of counterparty risk to which they are exposed. The second, more prominently voiced rationale refers to the fact that financial institutions, especially those of systemic importance, deserve special treatment. This is because they handle risks that can rapidly turn incalculable, and because of the probability of contagion in the market should one of these systemically important institutions fail. ${ }^{11}$ This situation, where a financial market participant fails because its own counterparty had failed before is often described as 'a domino of insolvencies' or, more generally, systemic risk. ${ }^{12}$ This second rationale is about decreasing overall systemic risk in the financial market.

However, the value of the special protection afforded by safe harbours may be questioned. ${ }^{13}$ Particularly in the wake of the latest financial crisis, safe harbours may be regarded as extending unjustified privileges to financial institutions which produce negative externalities overall, not least since their cost is borne by nonfinancial market participants and other stakeholders, including society as a whole. Safe harbours may be suspected of destroying real economic value, of increasing rather than reducing systemic risk, and ultimately of allowing the socialisation of the financial industry's losses and thus of promoting moral hazard. In the end, they may turn out to be no more than the product of path-dependent legislation

securing an obligation in the financial market, so called title-transfer collateral, which is an agreement where the obligor transfers full (legal and beneficial) title over assets which are to be re-transferred once the debt has been discharged. Also, 'traditional security interests' helps to avoid confusion with 'securities', such as, in particular, shares and bonds.

11 See Unidroit Principles on Close-out Netting (n 1), Principle 4 - Key Considerations. When Safe harbours where introduced in the USA in 1978, stability of the commodities market was the main rationale, on which later expansions were equally built: American Bankruptcy Institute (ABI), Commission to Study the Reform of Chapter 11 - Final Report and Recommendations (2014) 94-95 < https://abiworld.app.box.com/s/vvircv5xv83aavl4dp4h> accessed 10 March 2015.

12 For an explanation of systemic risk, see GG Kaufman and KE Scott, 'What is systemic risk, and do bank regulators retard or contribute to it?', The Independent Review VII 3 (2003), 371-391.

13 See RR Bliss, and GG Kaufman, 'Derivatives and Systemic Risk: Netting, Collateral, and Closeout', Federal Reserve Bank of Chicago Working Paper 2005-3 (2005) <http://papers.ssrn.com/sol3/papers.cfm?abstract_id=730648> accessed 10 March 2015; FR Edwards and ER Morrison, 'Derivatives and the Bankruptcy Code: Why the Special Treatment?' (2005) 22 Yale Journal on Regulation, 91-122; SL Lubben, 'Derivatives and Bankruptcy: the Flawed Case for Special Treatment' (2009) 12-1 University of Pennsylvania Journal of Business Law 61-78; 'Repeal the Safe Harbors', (2010) 18 American Bankruptcy Institute Law Review 319-335; The Bankruptcy Case without Safe Harbors' (2010) 84 American Bankruptcy Law Journal 123-144; E Perotti, 'Systemic Liquidity Risk and Bankruptcy Exceptions' (2010) DSF Policy Paper Series No 8 <http://dare.uva.nl/document/2/114634> accessed 10 March 2015; JM Peck, R Mokal and T Janger, 'Financial Engineering Meets Chapter 11 Safe Harbors and the Bankruptcy Code' (2011) <http://discovery.ucl.ac.uk/1402065/1/Peck, \%20Mokal\%20and\%20Janger \%20on\%20Safe \%20Harbors $\%$ 20and $\% 20$ the $\% 20$ Bankruptcy \%20Code.pdf $>$ accessed 10 March 2015; MJ Roe, 'The Derivatives Market's Payment Priorities as Financial Crisis Accelerator' (2011) 63 Stanford Law Review 539-589; D Duffie and D Skeel, 'A Dialogue on the Costs and Benefits of Automatic Stays for Derivatives and Repurchase Agreements' University of Pennsylvania Law School Institute for Law and Economics, Research Paper No. 12-2 (2012) < http://papers.ssrn.com/sol3/papers.cfm?abstract_id=1982095> accessed 10 March 2015. DA Skeel and TH Jackson, 'Transaction Consistency and the New Finance in Bankruptcy' (2012) 112 Columbia Law Review 152-202; SL Schwarcz and O Sharon, 'The Bankruptcy Law Safe-Harbor for Derivatives: a Path-Dependence Analysis', (2014) 71 Wash \& Lee Law Review 1715-1755; ER Morrison, MJ Roe an CS Sontchi, 'Rolling Back the Safe Harbours' (2014) <http://papers.ssrn.com/sol3/Papers.cfm?abstract_id=2484565> accessed 10 March 2015. 
originating in the banks' own lobbying efforts. Therefore, curtailing or even abolishing safe harbours and leading financial institutions back into the 'regular' insolvency regime may help to dismantle the aforementioned distortions and decrease the risks inherent in the financial market.

Discussing these assumptions takes us straight back to the two prongs of the rationale of safe harbour rules. Again, as we know from the context of traditional security interests, it is debatable to what extent there is overall social and economic value in allowing parties to circumvent the pari passu baseline of distribution through private bargaining, leading to a shift of the risk away from those with higher bargaining power (typically banks) to the broader economy. It is ultimately the legislator who transforms the result of that debate into a normative policy decision as to the extent to which insolvency privileges are available. ${ }^{14}$

My main goal is to remove the biases that have dominated the debate so far. Therefore, this article places the safe harbours into a broader context, notably by looking at jurisdictions other than the US and by adopting a cross-jurisdictional view, as opposed to an idiosyncratic one which is incongruent with the international character of financial markets. Furthermore, I believe that insolvency law cannot be considered in isolation but must be viewed together with other areas of law, notably financial regulation. ${ }^{15}$ In particular, the new global soft law standards, especially those set by the G20 States, are currently gaining unprecedented momentum and are likely to dominate the debate to a much greater extent than will considerations of domestic insolvency law policy. Regulation is an area of the law that has far greater impact on risk mitigation in the financial market than insolvency law could ever achieve. This issue ties in with the dispute on the insolvency 'axioms," ${ }^{16}$ i.e. the question of what insolvency law can and should achieve, in particular in motivating market participants to adopt a certain type of conduct while they are still going concerns.

In the second section, I will widen the perspective to jurisdictions other than the US since the picture there is quite different. However, differences between jurisdictions relate not so much to the safe harbour regime (which is fairly homogeneous globally speaking) as to the gap between the safe harbour, on the one hand, and the generally applicable insolvency regime, on the other hand: in the US, that gap is considerably more pronounced than it is in other jurisdictions (England, Germany, Italy and Belgium will serve as examples here). As a result, the polarity between the treatment of the financial and the non-financial world which generally informs the debate in the context of debtor-friendly US bankruptcy law - is the exception rather than the rule. It will become clear that

\footnotetext{
14 See V Finch, Corporate Insolvency Law (2nd edn, Cambridge University Press 2009) 601.

15 The differentiation between financial 'law' and financial 'regulation' is not very clear and partly nonsensical. However, for the present purpose one might think of 'law' as addressing horizontal rights between, in particular, creditors and debtors or owners and non-owners, whereas 'regulation' addresses the vertical State-to-market relationship, mainly working on the basis of orders, prohibitions and sanctions for non-compliance.

16 DG Baird, 'Bankruptcy's Uncontested Axioms' (1998) 108 Yale L J 573-599; See V Finch, 'Security, Insolvency and Risk: Who Pays the Price' (1999) 62 Modern Law Review 633-670.
} 
jurisdictions with a more creditor-friendly approach to insolvency policy are much more inclined to embrace the notion of insolvency safe harbours.

The third section addresses the less prominently discussed, but probably more relevant rationale for safe harbours, that of increased liquidity. ${ }^{17}$ Much like the rationale underlying traditional security interests, which are typically introduced to strengthen lending markets, ${ }^{18}$ safe harbour rules allow for more liquidity in the relevant derivatives and repo markets. However, the economic advantages of safe harbours go far beyond the known effects of traditional security interests. They create remarkable flexibility across different types of asset, i.e. money, claims and securities. At the same time, they do away with certain legal categorisations, in particular that between collateral provided under a full title transfer, on the one hand, and collateral provided by means of creating a traditional security interest, on the other hand. This gives financial institutions scope for a type of risk management where all positions may be used for all purposes and throughout all jurisdictions that admit safe harbours. Under the safe harbour protection, the use of collateral becomes extremely efficient-or, viewed from a different perspective, it would be fair to say that safe harbours allow the available collateral cover to be stretched more and more thinly.

The fourth section addresses the reduction of systemic risk as the more prominent rationale for providing safe harbours. While the base argument - i.e. that reducing individual counterparty risks leads to reduced overall systemic risk - looks relatively straightforward, there would appear to be two potential antagonists to the effect of safe harbours which render a discussion much more complex. The first antagonist is moral hazard. It stands to reason that considerably lower counterparty risk is likely to trigger a more lenient approach to matters of creditworthiness of counterparties - however, whether this will lead to a riskier market overall remains difficult to assess. It is equally unclear whether it should be the role of insolvency law at all to control market participants' conduct while they are going concerns. The second antagonist is the effect of mass liquidation in the event of failure of a financial institution. Safe harbours may rapidly cause the liquidation of the greater part of the portfolio, thereby triggering collateral shortages affecting the entire market. Discussing both antagonists leads us straight into the question of the growing role of regulation in limiting systemic risk. To begin with, bank resolution regimes are now being introduced all over the globe. These are novel administrative measures that fall outside traditional categories of insolvency proceedings and are precisely aimed at avoiding the systemic impact of bank failures. Furthermore, there are now regulatory measures (some under preparation, others already implemented) focused on specific aspects of avoiding

\footnotetext{
17 'Liquidity' is the ability to sell any asset for other assets or cash at will, K Pistor, 'A Legal Theory of Finance' (2013) 41 Journal of Comparative Economics 315-330, 316.

${ }^{18}$ See Finch, ibid 637.
} 
systemic risk. As a consequence, the immediate relevance of systemic risk mitigation through safe harbours is considerably reduced.

The final section pulls together the various aspects and attempts to draw an overall picture of the value of safe harbours. It concludes that safe harbours in their current form are necessary for a functioning derivatives and repo market and for the modern financial market as a whole, and that they have highly positive effects on liquidity - it is true that the collateral cover in the market can be stretched very thinly on the basis of safe harbours but this effect is better controlled by regulation. In that sense, the systemic risk rationale for safe harbours is somewhat at odds with reality. Insolvency law should not be concerned with attempting to mitigate systemic risk in the market: despite its obvious influence on managerial decisions it is too bold a concept and not suitable for controlling the behaviour of financial institutions. Measures belonging to the sphere of financial regulation, such as those mentioned above, are much more effective in this regard. These measures are compatible with and complementary to safe harbour rules. It would be highly counterproductive to repeal or restrict the latter.

\section{THE SIGNIFICANCE OF THE PRIVILEGE19}

When a market participant fails or becomes insolvent, each and every one of its business partners will face three fundamental questions: ${ }^{20}$ first, am I bound to those of our contracts that are still open, or may I terminate and liquidate them? Secondly, do I have swift access to the collateral or security provided in my favour (if any) or do I need to wait before I can enforce it? Thirdly, are earlier actions of my counterparty which were in my favour, such as recent payments or recent delivery of security or collateral, potentially subject to avoidance by the insolvency official or court? The answers provided by insolvency laws around the world may differ: the solvent party may or may not be allowed to terminate the contracts, it may or may not be allowed to enforce the collateral, and the extent to which recent acts beneficial to certain creditors are subject to avoidance by the insolvency official or court differs, too. These questions are particularly important for financial institutions, especially in respect of their derivative contracts, repurchase agreements or similar transactions with the insolvent party. It is not uncommon for two financial institutions to have hundreds or even thousands of open financial contracts with one another at any given point in time. Therefore, the answers provided by insolvency law to the aforementioned questions generally affect contracts and collateral of an enormous combined value.

\footnotetext{
${ }^{19}$ I am grateful to Giulia Pecce and Sebastiaan Bierens, both research assistants at the LSE Department of Law, for researching the relevant Italian and Belgian law referred to in this section.

${ }^{20}$ See Mooney, 'The Bankruptcy Code’s Safe Harbors' (n 9) 249.
} 
The insolvency laws of most developed financial markets ${ }^{21}$ generally take a favourable approach to the financial industry and their financial contracts: contracts can be terminated and the collateral swiftly enforced and, generally, earlier payments or delivery of collateral cannot be avoided by the insolvency official. These, in plain language, are the effects of safe harbour rules. This approach is remarkably homogeneous across developed markets. ${ }^{22}$

However, safe harbours are more of an exception to generally applicable insolvency law in some jurisdictions than in others, largely because the starting point of the general insolvency law rules is different. In other words, the 'privilege' can be more or less significant. The critique voiced by US authors is partly based on the argument that the treatment of the financial industry is diametrically opposed to the treatment afforded to other, non-financial market participants: ${ }^{23}$ non-financial counterparties are not allowed to terminate in the run-up to insolvency, nor can they access their collateral, nor are they subject to avoidance by the insolvency official or court. However, this polarity is particularly pertinent to US law. As will be shown below, in other jurisdictions the picture is different simply because the starting point of insolvency law is different. Accordingly, it would be inappropriate to transplant the debate from the US to other jurisdictions without first examining these differences.

One clarification is in order here. Comparing the relevant US and EU laws poses a structural difficulty from the outset. In the US, the safe harbour rules are federal law contained in the United States Code. ${ }^{24}$ They form part of the general provisions of Title 11 'Bankruptcy', and as a consequence apply in both Chapter 7 'Liquidation' and Chapter 11 'Reorganisation'. The Code is directly applicable and self-contained. EU law contains a relevant set of rules spread over a number of instruments, most prominently (but not exclusively) the Financial Collateral Directive and the Banks' Winding-up Directive. ${ }^{25} \mathrm{EU}$ directives are not directly applicable or self-contained and therefore do not afford much insight into legal reality. They require implementation into national law, i.e. their rules are cast into the relevant domestic statutes, such as domestic insolvency law, secured transactions law, bank regulation and other statutes. As a consequence, we have not a single set of EU safe harbour rules but 28 of them. This article duly looks at

\footnotetext{
21 At the moment, ISDA refers to 43 jurisdictions as having close-out netting-friendly legislation, i.e. insolvency safe harbour rules, in place <http://www.isda.org/docproj/stat_of_net_leg.html\#f1 $>$ accessed 10 March 2015.

22 E.g., see the US and European rules listed in n 25, n 34, and n 43.

${ }^{23}$ Lubben, 'Repeal the Safe Harbors' (n 13) 322-326; Roe, 'The Derivatives Markets Payment Priorities' (n 12) 547-549; Morrison, Roe and Sontchi, 'Rolling Back the Repo Safe Harbors' (n 12) 4-8.

24 On the gradual expansion of the USC safe harbours see M Krimminger, ,The Evolution of U.S. Insolvency Law for Financial Market Contracts' (2006) Working Paper $<$ http://papers.ssrn.com/sol3/papers.cfm?abstract_id=916345> accessed 10 March 2015.

25 Directive 2002/47/EC of the European Parliament and of the Council of 6 June 2002 on financial collateral arrangements, OJ L168/43 of 27.6.2002; Directive 2001/24/EC of 4 April 2001 on the reorganisation and winding up of credit institutions, OJ L125/15 of 5.5.2001. See on the EU framework P Paech, 'Close-out Netting' (n 6) 434-439.
} 
EU law through the filter of concrete jurisdictions with different legal traditions, notably England and Germany, Belgium and Italy. The respective legal regimes for the treatment of financial contracts in insolvency differ slightly, as the standards set by the relevant EU directives are not very detailed and allow for considerable differences in implementation. In addition, where the national law was already in line with the requirements set by the relevant EU directives, formal implementation was not required, which means that the directive can be considered as having been implemented without any actual changes having been made to the national law.

\section{LIQUIDATION OF CONTRACTS}

The principal building block of master agreements consists of provisions allowing one party to liquidate, en bloc, all executory contracts should a termination or default event occur. The term 'close-out netting' is often used instead of liquidation in that context. Close-out netting involves a number logical steps: first, termination of the relevant bundle of contracts; secondly, determination of the value of each contract; thirdly, set-off of the positive and negative values so that only a net balance is owing; and, fourthly, acceleration of the resulting payment obligation. ${ }^{26}$ The safe harbour rules ${ }^{27}$ of the relevant forum ensure that the closeout netting mechanism contained in the master agreement remains enforceable beyond the counterparty's insolvency. ${ }^{28}$

In US law, by contrast, termination of executory contracts upon insolvency motivated solely by the financial position of the insolvent ('ipso-facto clause') is expressly prohibited and the set-off of any debt owing to the debtor is stayed from the moment the petition is filed. ${ }^{29}$ Also, the trustee can cherry-pick, choosing contracts favourable to the insolvent estate and rejecting the others, thus disintegrating what was originally intended for liquidation en bloc. ${ }^{30}$ As a result, the non-defaulting party must perform on contracts that are unfavourable from its point of view or else pay damages (largely corresponding to the replacement cost)

\footnotetext{
26 The liquidation mechanisms provided for in the different master agreements do not necessarily work exactly in the same way but the functional result remains the same, see Unidroit Principles on Close-out Netting (n 1), Principle 2 with commentary.

27 Articles 4(4), 7(4) Financial Collateral Directive; 11 USC S\$ 362(b)(6)-(7)-(17)-(27) and (o); 555-556, 559-561; s12(1) Financial Collateral Arrangements (No. 2) Regulation (UK); \$104 Insolvenzordnung (Germany); Article 14 Loi relative aux sûretés financières (Belgium); Italy: Article 7 Decreto legislativo n. 170 in material di contratti di garanzia finanziaria. For a generic functional clause, see UNIDROIT Principles on Close-out Netting, Principle 7 with commentary. There are three different ways of allowing liquidation of contracts after opening of insolvency proceedings, notably carve-out, plain reference or mandatory statutory rule, see, Paech, 'Close-out Netting' (n 22), 430-431.

28 As long as parties are solvent, contractual provisions to that effect are unproblematic and can be freely operated as an expression of the principle of freedom of contract. However, should a party become insolvent, that principle might be overridden by mandatory rules of insolvency law, thus hindering in particular termination and set-off of the bundle of contracts.

2911 USC $\$ ₫ 365(\mathrm{e})(1)$ and $541(\mathrm{c})(1) ; \$ 362(\mathrm{a})(7)$. Ipso facto clauses where still permitted under the US Bankruptcy Act of 1908: R.M. Goode, "Perpetual trustee and flip clauses in swap transactions" (2011) 127 LQR $1,8$.

3011 USC \365(a).
} 
for non-performance, yet will receive only part of the damages provided for those broken contracts that are favourable to it. It is worth emphasising that these principles apply not only in the context of reorganisation proceedings but also in the event of liquidation, evidence that the idea of saving a business is paramount in US bankruptcy law, or, in other words, of its pronounced debtor-friendliness.

By contrast, other jurisdictions are less debtor-friendly and more creditorfriendly, regardless of whether they belong to the common law or the civil law tradition. Most prominently, England is much more creditor-friendly, and the general legal position in respect of liquidation of contracts upon insolvency was traditionally such that the later implementation of the EU Financial Collateral Directive did not require fundamental changes to the regime in place. In England, termination and set-off upon insolvency have always been possible, also in a nonfinancial context. ${ }^{31}$ Under German law, the treatment of non-financial scenarios is much closer to the English position than to that of the US, with far-reaching termination and set-off rights also for non-financial counterparties. ${ }^{32}$ Belgium has

31 Termination upon insolvency is considered on the basis of the anti-deprivation principle, according to which a contractual provision cannot stipulate insolvency as an event that is to deprive the debtor company of an asset held at the time of the commencement of insolvency proceedings. The principle applies in both the winding-up and the administration scenario (Belmont Park Investment Pty $v$ BNY corporate Trustee Services Ltd [2011] UKSC 38, [2011] 3 WLR 521, affirming Perpetual Trustee Company Ltd v BNY Corporate Trustee Services Ltd [2009] EWCA Civ 1160, [2010] Ch 347). Agreements to terminate a limited interest conferred on another, or providing for automatic termination of that interest, if that other becomes insolvent do not contravene the anti-deprivation rule (RM Goode, 'Perpetual Trustee and Flip Clauses in Swap Transactions' (2011) 127 Law Quarterly Review 1, 8). The underlying idea is that insolvency law does not override freedom of contract where no question of a sham transaction has arisen (Lord Neuberger MR in Perpetual Trustee, ibid, at [91]. Cf the parallel reasoning of the Bundesgerichtshof, $n$ 32). As regards set-off, in England insolvency set-off kicks in upon commencement of the proceedings, which applies to all mutual credits, debts, or other mutual dealings between the insolvent and its counterparty (Insolvency Rules 1986 (as amended), rule 2.85 (for administration) and rule 4.90). It is mandatory, retroactive and self-executing (MS Fashions Ltd v Bank of Credit and Commerce International S $A$ (No. 2) [1993] per Hoffman LJ at 432-433; Stein v Blake [1996] 1 A.C. 243 per Lord Hoffmann at 253). However, it does not cover executory contracts but only obligations. Therefore, in principle, the liquidator has general cherry-picking powers (Insolvency Act 1986 s 178(3)). Still, as termination remains possible, parties can always agree on automatic termination should one of them become insolvent which would turn their executory contracts into simple payment obligations to which mandatory insolvency set-off would then apply (Goode, Principles of corporate insolvency law, para 9-43). See also Peck, Mokal and Janger, 'Financial Engineering' (n 8), 4-6.

32 Termination clauses are only void to the extent that they refer to the commencement of proceedings as the relevant trigger (Insolvenzordnung $\left.\int 119\right)$, but are valid as a matter of contractual freedom if they refer to an event prior to commencement, such as default or filing of the bankruptcy petition, since the insolvency official has to accept the estate as is (BGH ZIP 1994, 40, 42; BGHZ 96, 34, 37-38. Note that the Bundesgerichtshof rejects the idea of any retroactive effect of the statutory ipso facto prohibition, whereas the English Court of Appeal (n 28), with the same reasoning, allows even ipso facto clauses that refer to insolvency itself as the trigger event.). As a consequence, contractual termination before commencement of proceedings remains enforceable. To the extent that there is no such termination clause, creditors are bound to their contracts and subject to cherry-picking. However, as a general rule which not only applies to financial contracts but generally, where forward contracts over assets that have an ascertainable market value or are quoted on an exchange stipulate performance for a postcommencement point in time, the insolvency official cannot choose performance. Instead, he can only claim a compensation payment, corresponding to the difference between market value and agreed price, provided the debtor is in the money; if the creditor is in the money, he has to prove for that difference in the proceedings. This means that such forward contracts are terminated by operation of law. Most 
introduced legislation that affords identical treatment in insolvency to financial and non-financial counterparties, which leaves only situations involving natural persons not acting in a merchant capacity to the general regime. The law expressly provides for close-out netting agreements to be enforceable. ${ }^{33}$ Lastly, the Italian legal regime is also applicable to non-financial scenarios and does not differ significantly from the framework applicable to financial institutions, ${ }^{34}$ although it makes an exception for large corporations. ${ }^{35}$

\section{SWIFT ACCESS TO COLLATERAL}

The second element of safe harbours relates to the timely enforceability of collateral in insolvency, i.e., to the question of whether a secured counterparty may have immediate recourse to the collateral assets. The general approach in respect of financial counterparties is that they can immediately enforce collateral provided by the insolvent, without prior authorisation or similar requirements. ${ }^{36}$

In the US, again, this contrasts with the general approach taken in respect of non-financial counterparties. Outside the safe harbours, enforcement of security or collateral requires prior application to the court called upon to grant relief in case of otherwise inadequate protection of the secured creditor or if the asset is not essential to effective reorganisation. ${ }^{37}$

This clearly contrasts with English law, where the general policy is very different from that in the US. In winding-up proceedings, creditors are largely unaffected by the liquidation process as they can remove their security from the pool and realise it. ${ }^{38}$ In administration (remotely comparable to US

importantly, though, set off continues to be available to the creditor even after commencement of proceedings, provided that the mutual claims existed at that point in time (Insolvenzordnung $\iint 54-96$. If claims become due or congeneric only in the course of the proceedings, set-off must wait until then. If obligations are in different currencies or units, conversion is possible to make them congeneric.). The continued availability of set-off combines with the validity of pre-commencement termination: termination values can be set off even if proceedings have commenced in the meantime.

33 Article 14 Loi relative aux sûretés financières.

34 Termination and close-out netting provisions in the context of reorganisation proceedings are enforceable and do not succumb to the relevant proceeding. Similarly, in the liquidation scenario, the enforceability of liquidation and close-out rights is not affected unless the competent court authorises the continuation of the business of the defaulting party. In that case, the termination of financial derivatives would be suspended until the continuation comes to an end but rights under the termination and closeout netting would 'revive' in case of default by the Italian party to pay scheduled amounts, notwithstanding the continuation of the business.

35 Within special reorganisation proceedings for large companies the right to terminate and set-off is not recognised. However, the insolvency officials of the relevant proceeding would probably not be allowed to cherry-pick outstanding transactions under the master agreement that are favourable to the defaulting party and reject those that are disadvantageous for the latter. Instead, the insolvency official's choice to continue the master agreement applies to the whole bundle of covered transactions.

36 See Article 4(4) and (5) FCD; UNIDROIT Principle 7(1)(a); 11 USC \ 362(b)(6)-(7)-(17)-(27) and (o).

3711 USC $\int 362(\mathrm{a})$ and $(\mathrm{d})$.

38 Goode, Principles of Corporate Insolvency Law, Sweet \& Maxwell, London 2011, para 8-47. Collateral can be used in the ordinary course of business without an application to the court; cash collateral may only be used with consent of creditor or the court. Only if the liquidator refuses to release the security asset must the creditor obtain leave of the court, which will almost invariably be granted since what is 
reorganisation), the approach is obviously different and closer to the US model, as the secured creditor is dependent on leave from the court to enforce its security; this will usually be granted if significant loss to the secured creditor is likely to result from a refusal. ${ }^{39}$ Only substantially greater losses caused to others by such leave may outweigh the interest of the secured creditor. ${ }^{40}$ This is where the implementation of the Financial Collateral Directive has a significant impact, as it explicitly abolishes the requirement of court approval for transactions that come within its scope. ${ }^{41}$

Under German law, the general position ${ }^{42}$ is that pledged movables are generally realised by the insolvency official for a secured creditor entitled to direct the manner in which the asset is realised and to whom immediate payment is made from the proceeds. Interest is due as from the day of the commencement of proceedings. The asset can also be transferred to the creditor if that is the most suitable solution. The insolvency official does, however, have the right to use the asset for the estate, in which case compensation has to be paid to the secured creditor for any deterioration of the asset affecting the security. In this respect, the German regime is comparable to the US model. The privilege afforded to financial counterparties consists in the fact that pledged financial collateral is exempt from this regime and can be realised by the counterparty unaffected by the commencement of proceedings. ${ }^{43}$ The Belgian Financial Collateral law provides for all market participants except natural persons - that the enforcement rights of those creditors benefiting from financial collateral are not suspended as long as the agreement creating the financial collateral was executed before the date of the bankruptcy order. The beneficiary of a share pledge has the right to appropriate the shares upon default of the pledgor. No prior notice or authorisation is required if appropriation is expressly permitted in the pledge agreement. ${ }^{44}$

\section{Protection against AVoidance}

The third element relates to avoidance. In the insolvency of a financial institution, its counterparties are privileged because the right of the insolvency official to avoid prior legal acts on the ground that they constituted preferential treatment of a creditor or was an undervalue transaction is heavily curtailed as compared to

involved is not property of the insolvent. Goode, ibid, referring to James LJ in Re David Lloyd \& Co (1877) 6 Ch. D. 339 at 344-345.

39 Insolvency Act 1986 Schedule B1 para. 43(2). But note the ability of the administrator to use cash collateral in case of a floating charge without consent of the creditor or court, ibid, para 70.

40 Nicholls LJ in Re Atlantic Computer Systems Plc [1992] Ch. 505 at 543.

41 Financial Collateral Arrangements (No. 2) Regulation 2003, reg. 8; it is however unclear whether the concept of 'control' captures floating charges, see Look Chan Ho, 'The Financial Collateral Directive's Practice in England' (2011) JIBLR 151, 158-159.

42 Insolvenzordnung $\int S 166,169,170,172$.

43 Insolvenzordnung $\int \$ 166(3), 173(1)$.

44 Article 8 Loi relative aux sûretés financières. Although no prior court approval is required, the law provides for the possibility for the courts to exercise some form of control afterwards, see Article 8(3)s. 
general insolvency law. 45 Again, the gap between general insolvency law and the privileged safe harbour regime may vary depending on the jurisdiction. However, as to avoidance, the picture differs from the findings of the foregoing sections. Here, the privilege afforded to financial institutions is of similar significance throughout, as robust avoidance rules for non-financial market participants exist in the US as well as in England, Germany, Belgium and Italy.

In the US, the general position is that creditors who have received payment or a security interest within 90 days prior to the commencement of bankruptcy proceedings are, as a rule, required to return it, except if the transfer was for value or undertaken in the ordinary course of business. ${ }^{46}$ In English administration or liquidation proceedings, where the creditor is not a financial institution, avoidance is possible in case of undervalue transactions for a period of two years, and in case of preferential treatment of a creditor for a period of six months ${ }^{47}$ However, the transaction cannot be avoided if, in an undervalue scenario, the insolvent company was in good faith and for the purpose of carrying on its business and there were reasonable grounds for believing that the transaction would benefit the company, or, respectively, in a preferential treatment scenario, unless the insolvent company was influenced in deciding to give it by a desire to prefer a given creditor. Under German law, transactions can be avoided for preference within a three-month period prior to commencement of proceedings if the creditor knew about the insolvency of the debtor or if it could not have been unaware of it. ${ }^{48}$ Undervalue transactions can be avoided without any further ado if they occurred during the last month before the commencement of insolvency proceedings, or if they occurred during the second or third month before insolvency if the debtor was insolvent at that point in time or if the creditor knew that other creditors would be prejudiced or if that fact was obvious to it. ${ }^{49}$ Belgian law contains a number of discretionary and automatic claw-back rules that apply during a six-month period prior to the commencement of proceedings, whereas avoidance of fraudulent transfers is not subject to a time limit. ${ }^{50}$ Under Italian law, transactions at undervalue are invalid if entered into during the two years prior to commencement of proceedings. Furthermore, payments falling due on the day of the commencement of proceedings or thereafter are equally void if made during that

\footnotetext{
${ }^{45}$ See 11 USC $\int 546(\mathrm{~g})$, (j); Article 8(1)-(3) Financial Collateral Directive. European jurisdictions are to a large extent free to set the parameters for avoidance as the Directive leaves this issue largely to the law of the Member States, exempting only a number of standard situations of constructive preferential treatment from avoidance. See also UNIDROIT Principles on Close-out Netting, Principle 7(1)(c)-(d). However, regularly, fraudulent transactions are not protected, see 11 USC $\$ 546(\mathrm{e})$; Recital 16 Financial Collateral Directive; Unidroit Principles on Close-out Netting, Principle 7(2).

4611 USC $\int S 547$.

47 Insolvency Act 1986, ss 238, 239. Avoidance for preference is possible during a two-year period if the preferred creditor is connected with the company, s 240.

48 Insolvenzordnung $\ 130$. Variation margins provided under financial collateral arrangements are expressly exempt. Interestingly, the rule expressly states that the exemption takes effect only to the extent that the additional margin reflects the changes in value of the secured obligation. This requirement seems to have been inserted to avoid the problem of systematic under-collateralisation, see text to n $98-105$.

${ }^{49}$ Insolvenzordnung $₫ 131$.

${ }^{50}$ Bankrupty Act (Belgium) of 8 August 1997, Articles 12, 17, 18 and 20.
} 
two-year period. Fraudulent transactions can be voided if entered into during a suspect period of six months or one year, depending on the type of transaction..$^{51}$

\section{EXPONENTIATED LIQUIDITY}

The strong polarity of the insolvency treatment of the financial sector, on the one hand, and of the non-financial sector, on the other hand, such as currently exists under US law, seems to be the exception rather than the rule. In other jurisdictions, the gap between the safe harbour regime and the general insolvency rules is much smaller and in some cases, the treatment of financial and nonfinancial scenarios is even identical or quasi-identical, at least as regards termination, set-off and swift access to collateral. The only exception is the regime for avoidance. Here, safe harbour rules afford considerable relief to the financial industry, not only in the US but also in other jurisdictions. The more obvious consequence of the above finding is that the perception of egregious privileges afforded to financial institutions can only be upheld in a domestic tunnel vision. ${ }^{52}$ Moreover, and more importantly, the above findings tie in seamlessly with the distorted view on the rationale for safe harbours. Liquidity as a main argument is not appropriate in a rather debtor-friendly environment such as the US Bankruptcy Code, which is why greater prominence is given, at least on the surface, to the systemic risk argument. In more creditor-friendly jurisdictions, which put greater emphasis on assets flowing back into the economy quickly, there is obviously more room for a rationale based on liquidity and market efficiency. .53

Unlike the case of traditional security interests, the liquidity rationale of safe harbours has never received the degree of prominence in the policy debate it would have deserved. ${ }^{4}$ This is surprising, also because it may be safely assumed, in the light of lessons learned from the latest financial crisis, that in lobbying for safe harbours, the financial industry was probably focused more on business development than on risk limitation. .5

\footnotetext{
51 Art 64-67 Italian Bankrupty Act.

52 See Morrison, Roe and Sontchi, Rolling Back the Repo Safe Harbors, 12: 'But if the safe harbours increase social welfare because they increase liquidity overall (and not just the benefited creditors at the expense of other creditors), then the safe harbours should apply to all secured debt, not just financial contracts.'

53 ISDA, Memorandum on the Template for Netting Legislation (March 2006).

<http://www2.isda.org/search?headerSearch=1\&keyword=model+netting $>$ accessed 10 March 2015.

54 See Bliss and Kaufmann, Derivatives and Systemic Risk, 15-16. See Recitals 12 and 19 Financial Collateral Directive. See also ISDA, Memorandum (n 53) where the word 'risk' appears eight times, whereas 'liquidity' is not mentioned at all; ABI, Reform of Chapter 11, (n 11) Section IV.E on 'Financial contracts, derivatives and safe harbour protection' mentions liquidity as a policy argument only once, and in the context of a side issue, whereas 'stability' is referred to eleven times.

55 See Bliss and Kaufman, Derivatives and Systemic Risk, 3.
} 
On the face of it, safe harbours produce economic effects quite similar to those associated with the protection of traditional security interests in insolvency. ${ }^{56}$ Because parties need not worry about their counterparty's solvency, derivatives and repo contracts become more easily available, and at a reduced cost, thereby considerably improving liquidity in these market segments. As a result, the basic economic effect of safe harbours is considerable growth in volumes of the relevant types of transaction (as could be observed in the run-up to the financial crisis, as repo markets doubled within 5 years ${ }^{57}$ ) and more efficient allocation of assets.

In considering whether to introduce insolvency privileges, legislators must take into account the fact that such privileges almost automatically entail a shift of the risk from one segment of the market to another, the latter being potentially a shift to 'weaker' creditors (as will be discussed later). In this regard, too, there are no fundamental differences between traditional security interests and safe harbours. Therefore, the basic assumptions about liquidity and the resulting discussion about the overall social value of insolvency privileges are very similar to those prevailing in the case of traditional security interests ${ }^{58}$ and will not be addressed here. Rather, I will concentrate on four novel effects of safe harbour rules that represent a quantum step in terms of increasing liquidity, in particular if taken in combination with one another.

\section{FLEXIBILITY ACROSS LEGAL CATEGORIES AND ASSET TYPES}

The risk mitigation techniques of master agreements (as protected by the safe harbour rules) are used to abolish established legal boundaries. In particular, differences between full title and security interest disappear, and boundaries between claims, cash and securities become blurred. This high degree of flexibility is nothing less than revolutionary, overthrowing traditional legal restrictions on the use of assets with a view to obtaining cash and creating liquidity more generally. This is the result of the combined use of the techniques available under safe harbour rules, notably enforceable termination and netting of contracts, enforceable collateral and limitation of insolvency avoidance. The EU Financial Collateral Directive contains a paradigmatic blueprint for this phenomenon. ${ }^{59}$

First, the differences between full title and security interests disappear because the safe harbours sanction the use of title transfer collateral, netting and 'margining'. ${ }^{60}$ Under such arrangements, while the collateral provider is protected

\footnotetext{
56 General reference e.g. to V Finch, 'Security, Insolvency and Risk' (n 16) 637-643.

57 See Bank for International Settlements, Quarterly Review, December 2008 <http://www.bis.org/publ/qtrpdf/r_qt0812e.pdf> accessed 10 March 2015.

58 See, e.g., V Finch, 'Security, Insolvency and Risk' (n 16); LA Bebchuk and J Fried, 'The Uneasy Case for the Priority of Secured Claims in Bankruptcy' (1996) 105 Yale Law Journal 857-934.

${ }^{59}$ See Articles 3-8 Financial Collateral Directive.

60 Margining is necessary because both the obligation and the value of the collateral asset typically change over time. Therefore, collateral levels are adjusted to the exposure on a daily basis. The obligation to post collateral might reverse in the course of the term of the contract.
} 
as efficiently as it would be under a traditional security interest such as a pledge or mortgage, the collateral taker enjoys far greater freedom to use the collateral assets than it would under a traditional security interest, in that it becomes the legal and beneficial owner of the asset and can therefore dispose of it, without being obliged to return that specific asset as long as the asset returned is of the same kind. What is remarkable here is that the rights of one party appear to grow whereas the risk borne by the other party remains unchanged.

Furthermore, the boundaries between claims, money and securities become blurred as the collateral provider can validly substitute new collateral assets for the assets originally provided, which it might need for other purposes. ${ }^{61}$ The only proviso is that the replacement assets must be of substantially equivalent value. As a consequence, the collateral provider is allowed to replace one kind of securities collateral for another, or give cash for securities collateral, or securities for cash collateral.

On that basis, the specificity of the collateral assets becomes as irrelevant as their nature (money, claims or securities). Positions become interchangeable and the collateral provider will collateralise all available assets as efficiently as possible, thereby creating maximum return. The fact that assets are freed from the conceptual burdens associated with legal limits to traditional security interests makes it possible to treat them as a mere accounting position, the only parameter being current market value. Thus, thanks to the existence of safe harbours, a derivatives and repo portfolio resembles a gigantic current account into which assets and liabilities, including collateral of whatever description, accruing under whichever type of arrangement, can be booked at current market value, so as to show the net exposure as a grand total.

\section{STRETCHING THE COLLATERAL COVER THINLY}

A phenomenon closely connected to the foregoing is the fact that safe harbour rules enable collateral to be allocated so efficiently that there will hardly be any collateral buffers around. Here, again, we are in the presence of a change in the legal environment brought about by the introduction of safe harbour rules.

The first aspect here is the effect of the enforceability of close-out netting on collateral levels. If a risk reduction of $80 \%$ can be taken for $\operatorname{granted}^{62}$, parties will,

61 'Substitution' describes a right to withdraw financial collateral on providing, financial collateral of substantially the same value, see, e.g., Article 8(3)(b) Financial Collateral Directive.

62 The Bank for International Settlements provides data illustrating the effect of close-out netting in relation to the example of the derivatives market (the effects are comparable in relation to the repo and securities lending market): the notional amount (face value) of all types of OTC contracts stood at approximately USD 693 trillion at the end of June 2013. The gross market value of these contracts, i.e., the cost of replacing all of them by equivalent contracts at the market price, was approximately USD 20 trillion. This amount corresponds to the gross market risk inherent in these contracts, i.e., market participants were, on an aggregate basis, exposed to each other by that sum. At the same time, market participants' aggregate actual credit exposures, i.e., the remaining credit risk taking into account legally enforceable master agreements, amounted to USD 3.9 trillion, which represents a risk reduction of about 
of course, only collateralise the remaining $20 \%$. Hence, much less collateral will be needed from the outset or, to put it differently, the same amount of collateral will suffice to cover a higher volume of transactions.

At the same time, master agreements make it possible constantly to adjust collateral levels to the underlying exposures so as to avoid over or undercollateralisation. These margining mechanisms rely on the safe-harbour limitation of avoidance powers as they might otherwise be classified as late provision of collateral.

Lastly, safe harbours enable the re-use of collateral assets by the collateral taker, given that the latter generally becomes their legal and beneficial owner. Therefore, as opposed to what is common in other markets (which are bound to traditional secured transactions, lack of safe harbour protection), the collateral taker will generally put the collateral assets to use instead of just 'holding' them, thereby maintaining the assets in constant flow.

The result of the foregoing is that asset allocation is extremely efficient throughout the market. However, by the same token, it may also mean that the cover becomes extremely thin, as there are no longer any pools of unused assets.

\section{SOURCING COLLATERAL GLOBALLY}

Collateral assets are scarce and sourcing them from a wider market would therefore be beneficial in terms of liquidity. However, before the broad introduction of safe harbour rules, financial institutions had to rely on domestic secured financing law. The diversity of mandatory insolvency and property law nurtured substantial doubts as to the cross-jurisdictional enforceability of close-out netting and collateral. ${ }^{63}$ Cross-border collateral was possible but complicated to arrange, and each arrangement was only compatible within the two jurisdictions involved. The most prominent move to address this issue was the introduction of the Financial Collateral Directive, which created a harmonised safe harbour regime across the EU. However, the phenomenon is not confined to the EU as safe harbour rules are relatively homogeneous throughout all jurisdictions that have developed financial markets, ${ }^{64}$ whereby the safe harbours of the Financial Collateral Directive are particularly broad. As a consequence, there is a harmonised legal space in which financial institutions can source and use collateral quasi-globally.

Harmonisation works through the congruent removal, in the relevant jurisdictions, of legal restrictions, in particular through the de facto abolition of traditional security interests in the context of derivative and repo transactions -

$80 \%$. See Bank for International Settlements, OTC Derivatives Statistics at End-June 2013 (November 2013), 2, available online at <http://www.bis.org/publ/otc_hy1311.pdf $>$, last accessed on 4 January 2014.

${ }^{63}$ See, regarding enforceability of collateral: P Paech, 'Market Needs as Paradigm - Breaking up the Thinking on EU Securities Law', in PH Conac, L Thévenoz and U Segna (eds), Intermediated Securities, (Cambridge University Press, 2013), 22-64; in relation to enforceability of close-out netting: 'Close-out Netting' (n 6).

${ }^{64}$ See above, $2^{\text {nd }}$ Section. 
collateral is now generally provided on the basis of full title transfer. The fact that there is now a level legal environment is illustrated by the circumstance that derivatives and repo transactions can be documented in most markets under the same master agreements. In particular, the ISDA Master Agreement gained global significance ${ }^{65}$ because its functionalities (termination, liquidation, set-off, collateral) are now recognised in the relevant jurisdictions. At the same time, the restriction of avoidance powers removes fears of re-characterisation, claw-back and similar court actions that would endanger the functioning of the risk mitigation mechanism. Despite the fact that many legal differences remain as to detail, it is probably fair to say that the market for collateral, and therefore the market for derivatives and repos, comes close to having a globally harmonised legal framework. ${ }^{66}$ The extensive introduction of safe harbour rules is actually a significant example of market-driven high-impact international legal harmonisation ${ }^{67}$, somehow silently overcoming statutory legal hurdles that parties could not derogate from. Mandatory insolvency and property law were typically the most considerable threats to enforceability of contracts. However, at statutory level, despite considerable efforts, States were to date unable to agree on a crossborder-compatible legal framework. ${ }^{68}$ Harmonisation on the basis of introducing safe harbours not only lessens the importance of domestic policy towards insolvency but also reduces the importance of legal considerations in risk management altogether.

\section{EFFICIENT USE OF REGULATORY CAPITAL}

Lastly, banking regulation sanctions the liquidity thus increased by the safe harbours. Notably, it recognises the net exposures used by financial institutions for risk management purposes also with a view to calculating capital requirements. Safe harbour rules are fundamentally important in this context because the relevant regulatory rules require absolute certainty that close-out netting and collateral will be enforceable in the event of insolvency. ${ }^{69}$ If that is so, banks are allowed to calculate their regulatory capital on the basis of net, rather than gross, credit risk exposures. As mentioned earlier, the average risk reduction through netting is roughly $80 \%$. In order to grasp the effect of this significant reduction, it may be helpful to recall that regulatory capital is not, as is often assumed, a

\footnotetext{
${ }^{65}$ See Briggs J in Lomas \& ors v JFB Firth Rixson, Inc \& ors [2010] EWHC 3372 (Ch) at [53].

66 Remarkably, the law governing the cross-jurisdictional transfer of property over securities is still entirely national and therefore probably the only piece of that globalisation puzzle that is still missing. ${ }^{67}$ See Bliss and Kaufman, Derivatives and Systemic Risk, 2.

68 The Geneva Securities Convention and the Hague Securities Convention, both addressing the issues of cross-border securities collateral, were adopted by a considerable number of States (amongst the those of the EU, the USA, Japan and many other major financial markets) but never ratified.

${ }^{69}$ Bank for International Settlements/Basel Committee on Banking Supervision, International Convergence of Capital Measurement and Capital Standards (Comprehensive version), June 2006, <www.bis.org/publ/ bcbs128.htm > ('Basel II Accord'), [117.], [118.], [139.], [188.]; Strengthening the resilience of the banking sector, (Consultative Document), December 2009, <www.bis.org/publ/bcbs164.pdf?noframes=1>, 43.
} 
requirement to hold certain cash reserves available. Rather, regulatory capital describes the ratio between risk exposure and the capital raised by issuing own shares. As a consequence of the recognition of net risk in a safe harbour environment, a bank is able to enter six times the gross risk in its balance sheet that it would otherwise be allowed to accept. ${ }^{70}$

The effect is two-fold. ${ }^{71}$ First, availability and liquidity of repo transactions are improved because absolute regulatory limits accommodate a higher volume where calculation on a net basis is allowed. In other words, safe harbours allow for more contracts under identical regulatory caps. This effect is not necessarily confined to derivatives and repo transactions but extends across the balance sheet to any other risk-taking activity such as ordinary lending. If less capital is needed as a consequence of safe harbours to match derivatives and repo transactions, ordinary lending activity may likewise be increased. The second effect is a costsaving element for banks, since share capital is a relatively expensive means of financing. If more contracts of a higher aggregate volume can be entered on the basis of the relevant available share capital base, the relative cost of share capital decreases.

\section{A SYSTEMIC RISK ZERO-SUM GAME?}

As we have just seen, safe harbours considerably increase efficiency and liquidity but may lead to the collateral cover being stretched thinly. The connection with the second - more prominent - rationale for safe harbours is obvious: the question of how much collateral is available is of immediate importance for systemic stability: more efficiency increases the availability of collateral which is generally beneficial—but overstretching is harmful because there will be no reserves when collateral becomes scarce.

Insolvency safe harbours have to date mainly been regarded as necessary to decrease the systemic risk inherent in the financial market, in particular to assist in avoiding the domino effect of bank insolvencies. ${ }^{72}$ The base argument builds on the fact that liquid derivatives and repo markets are essential to the overall efficiency of the financial markets. However, the reference values in derivative transactions and the value of collateral assets are subject to daily fluctuations,

\footnotetext{
70 By way of simplified example: a bank's derivative and repo portfolio is taken into account at a gross risk of 1000 GBP because there are no safe harbours. This risk needs to be matched, at the current minimum rate of $10.5 \%$ regulatory capital, by 105 GBP in own share capital. In other words, the amount of issued share capital limits the possibility to take on more risk. However, if netting is allowed the bank can, on the basis of the same 105 GBP in share capital, enter into contracts exposing it to a gross risk of $5000 \mathrm{GBP}$ if we assume that close-out netting reduces the gross risk by $80 \%$.

${ }^{71}$ See Paech, Unidroit Doc 2.

72 See, in particular, Basel Committee on Banking Supervision, Report and Recommendations of the Cross-Border Bank Resolution Group (2010), 36-40 <http://www.bis.org/publ/bcbs169.pdf> accessed 10 March 2015. For US legislative history see Mooney, 'The Bankruptcy Code’s Safe Harbors' (n 9) $247-$ 251.
} 
necessitating frequent, even daily adjustment of relevant collateral levels to manage the risk efficiently. That risk mitigation mechanism would lose its effectiveness should one of the parties become insolvent and should normal insolvency tools apply, such as, in particular, cherry-picking and the stay on termination and setoff. ${ }^{73}$ In other words, derivatives and repo transactions need specific exemptions from the usual 'threats' that flow from the opening of insolvency proceedings. First, the insolvency of one of these institutions could provoke the failure of its counterparties which, alone or jointly, might in their turn bring down others, sparking off a chain reaction. Secondly, there is significant potential for transmission of liquidity problems between market participants. Thus, the limitation (or near-elimination) of individual counterparty credit risk is expected to have a beneficial effect on systemic stability. In other words, privileges afforded to counterparties of a failing institution would translate into systemic stability and therefore into advantages benefiting the market as a whole. This argument is particularly relevant to the financial sector, even more than to other sectors, such as automotive, as financial institutions are so closely intertwined. ${ }^{74}$ Network externalities are therefore much more likely to occur than they are in other industries, and furthermore spread from the financial sector throughout entire economies. ${ }^{75}$ On the basis of this broad argument, safe harbour rules have been successively introduced in over 40 jurisdictions.

However, in light of the significant economic benefits that come with safe harbours, some authors regard them as the result of path-dependent legislation originally set off by banks' own lobbying efforts. ${ }^{76}$ These, they argue, should now be considerably restricted or repealed altogether, since they actually created systemic risk rather than curbed it. ${ }^{77}$ The reasons brought forward in relation to this argument are appealing, and the picture is certainly a complex one. The recent introduction of bank resolution regimes has addressed these concerns directly by introducing a short 2-day stay on liquidation (which is imposed by regulatory order and prohibits any termination, set-off or enforcement of collateral), expressly conceived to avoid adverse the systemic effects of liquidation. Thus, while, on the one hand, credit risk contagion is effectively inhibited by close-out netting and collateral as protected by safe harbour rules, it is also true that, on the other hand, these mechanisms can at the same time develop adverse systemic effects through other transmission mechanisms. ${ }^{78}$ Broadly speaking, relevant examples fall into two categories of risk transmission mechanism, to wit, moral hazard and collateral/liquidity shortages.

\footnotetext{
${ }^{73}$ See Unidroit Principles on Close-out Netting, Principles 6 and 7.

${ }^{74} \mathrm{Cf}$. Edwards and Morrison, 'Derivatives and the Bankruptcy Code' (n 12) 11.

75 Bliss and Kaufman (n 12), 'Repeal the Safe Harbors' (n 12) 329

${ }^{76}$ Schwarcz and Sharon, 'The Bankruptcy Law Safe-Harbor' (n 12).

${ }^{77}$ Lubben, 'Repeal the Safe Harbors' (n 12); Roe, 'Derivatives Market Payment Priorities' (n 12).

${ }^{78} \mathrm{~K}$ Pistor (n 17) sections 3.2 and 4.3 provides evidence that the antagonising effects of financial law, ie, creating and threatening liquidity at the same time, are a general and logical characteristic of the market.
} 
While these two typical systemic risk transmitters can, in principle, antagonise the systemically beneficial effects of safe harbours, it would not make sense to analyse this interdependency in isolation. Regulation is much more relevant to the limitation of systemic risk and directly addresses the relevant contagion mechanisms other - often novel - measures. This leads to the question of whether the important influence insolvency law has on conduct makes it an appropriate means to control systemic risk and the behaviour of market participants while they are going concerns. In the following sections, I shall attempt to combine these aspects to form an overall picture.

\section{MORAL HAZARD}

Safe harbours create a transaction environment for financial institutions that is almost entirely free of counterparty risk. This places financial institutions in a privileged position as compared to other, non-financial counterparties (although, as discussed in the second part of this article the degree of privilege differs from one jurisdiction to another ${ }^{79}$ ). Thanks to these privileges, risk is shifted to nonfinancial counterparties, which alone have to bear the specific cost of bankruptcy. In that, safe harbour rules have an effect quite comparable to that of traditional security interests.

The existence of such a privilege is bound to affect the perception and conduct of market participants generally. As a result, the existence of safe harbours may provoke moral hazard. ${ }^{80}$ In the context of financial regulation, the term 'moral hazard' describes a mechanism whereby real or presumed guarantees and other risks shift away from the financial sector and render the financial market more risk-prone on an aggregate basis. The phenomenon has been identified as a major driver of the 2007-2009 financial crisis. For years, financial institutions had enjoyed high income generated by excessive risk-taking in the expectation that the cost of failure would be socialised. After the crisis, a number of regulatory changes were introduced in an attempt to tame moral hazard, with a view to re-allocating to financial institutions and their stakeholders the risk they themselves create. ${ }^{81}$

Shifting the risk as such does not necessarily entail moral hazard. All kinds of insolvency privileges shift risk around the various types of creditors of the

\footnotetext{
${ }^{79}$ See second Part. Even insolvency privileges less significant than those provided for in the USA under USC Title 11, notably in more creditor-friendly jurisdictions, such as England and Belgium, and to some extent Germany and Italy, still provide more favourable treatment in relation to the three main concerns identified above. Some of the privileges may only come into play on the fringes, yet termination and setoff rights are better protected and collateral can be enforced more easily as compared to standard situations. Protection against avoidance of pre-insolvency transactions is considerably better in all jurisdictions.

80 Roe, Derivatives Market Payment Priorities, 545. See Baird, Bankruptcy's Uncontested Axioms, 578, 589-592.

81 These measures include remuneration of bank managers; higher bank capital requirements, new bank resolution regimes, stricter regulation of derivatives introduction of anti-cyclical capital and liquidity buffers, and others. See for an overview of all EU initiatives < http://ec.europa.eu/finance/generalpolicy/policy/map_reform_en.htm\#row7> accessed 10 March 2015.
} 
insolvent. The question, rather, is whether that shift entails a behavioural pattern that increases the risk overall, i.e., whether the level of systemic risk in the market as a whole increases.

Such an overall rise in systemic risk could be caused in particular by market inefficiencies. Already in relation to traditional security interests, the possibility for bigger players to demand security indirectly subsidises their businesses at the cost of certain other players, since the latter are unable to adjust to the increased risk. ${ }^{82}$ The effect of the risk transfer caused by insolvency safe harbours is similar: parties to whom risk is shifted are generally remote from the financial sector and as a result lack the ability to monitor the shift and adjust their own behaviour, in particular by demanding a higher risk premium or by not entering into the relevant position or quitting it altogether. ${ }^{83}$ The risk-taming effect of corrective behaviour at that end of the market is lacking, and this in turn renders the distribution of risk inefficient and the market overall riskier. It is worth noting that this shift of risk is global, as in practice all eligible creditors will take the necessary steps to get ahead of the pool by using the safe harbours. ${ }^{84}$ The risk is shifted to those that have no means of improving their position in any insolvency proceedings: in particular depositors, unsecured bond holders, share holders and 'ordinary' creditors of the insolvent. It is true that only few of these market participants are non-adjusting in the proper sense, traditionally retail depositors (which are now protected often protected by own preferences and/or deposit insurance) and ordinary creditors. However, mindful of the too-big-to-fail phenomenon, to which safe harbours contribute by allowing for exponential growth of the derivatives and repo markets, the State has traditionally assumed the risk as a whole, so that even adjusting creditors have no need to take the shift of risk into account. ${ }^{85}$

Furthermore, security may distort managerial diligence in the choice of counterparties. ${ }^{86}$ As before, this argument can be translated into the context of insolvency safe harbours: financial counterparties rely exclusively on the riskmitigation tools guaranteed under the safe-harbour regimes instead of investing into ex ante and on-going monitoring of their counterparties. ${ }^{87}$ Yet, this overreliance on safe harbours could also lead to moral hazard. ${ }^{88}$ By contrast, if, in

\footnotetext{
82 See Finch, 'Security, Insolvency and Risk'(n 16) 639.

83 Edwards and Morrison, Derivatives and the Bankruptcy Code, 32, 34; Roe, Derivatives Market Payment Priorities, 570; V Finch, Security, Insolvency and Risk - Who Pays the Price?, 62 Modern Law Review (1999), 633, 644-645 (in relation to traditional security interests).

${ }^{84}$ See Finch, Corporate Insolvency Law, 36.

85 See Roe, Derivatives Market Payment Priorities, 558-559; Peck, Mokal and Janger, 'Financial Engineering' (n 8), 12. It is debatable whether this holds true in all respects. The implicit State guarantee for banks might be regarded as the price paid for having energetic, growth-producing and stimulating financial markets. Although recent regulatory initiatives attempt to remove the State guarantee completely, it is not absolutely certain whether financial markets that go beyond pure utility banking can be governed in a way that makes bail-outs completely unnecessary in the future. See also more generally Pistor, A Legal Theory of Finance, (n 17) 323.

86 See Finch, Security, Insolvency and Risk, 646.

87 Roe, Derivatives Market Payment Priorities, 560-561.

88 Roe, ibid.
} 
the absence of safe harbours, monitoring were a necessity, any concentration of risk on certain players would be detected and priced in by potential counterparties; as a consequence, there would be more players with smaller risk portions in the market, and the market more diversified overall. ${ }^{89}$ Moreover, in times of crisis, with falling or unclear collateral value, the information obtained through monitoring would allow lending to continue as healthy counterparties could continue to operate even in adverse times. ${ }^{90}$

However, it is moot whether a case of moral hazard can be built on the foregoing. It is not evident that the market becomes riskier overall, as compared to the hypothetical alternative, a market without safe harbours. Hard evidence of such a connexion is difficult to establish and is often attempted with an eye to a preconceived result. ${ }^{91}$ To begin with, obviously, improved monitoring is always beneficial. ${ }^{22}$ Yet the value of monitoring highly complex, international and interconnected counterparties is limited. Comprehensive data regarding the counterparties is unlikely to be available. Even where such data is available, its value is limited as counterparties' balance sheets are not static and are subject to network externalities, since the riskiness of assets depends on the market as a whole. ${ }^{93}$ Therefore, the available data says little about the riskiness of a balance sheet in times of stress. In other words, monitoring counterparties to prevent risk is generally useful but not as powerful a tool as reducing counterparty risk through security, collateral and close-out netting - for which the existence of safe harbours is essential.

Speaking more generally, moral hazard, together with the too-big-to-fail argument, are amongst the main phenomena that have been identified as the origins of the recent financial crisis. They are not triggered by the existence of safe harbours alone but by an amalgam of causes and incentives and, probably, the fundamental socio-economic set-up of the financial market as a whole. Repealing or restricting safe harbour regimes is not, therefore, necessarily a suitable means of removing moral hazard, in particular because safe harbours are foremost concerned with enforceability of contractual rights and only have an indirect influence on behaviour. Instead, measures explicitly designed to address moral hazard and to-big-to-fail are more focussed and therefore more effective, such as bank resolution (discussed below), structural reforms cutting down the size and interconnectedness of banks and reform of pay structures that dis-incentivise excessive risk taking. ${ }^{94}$ These measures address moral hazard and to-big-to-fail

\footnotetext{
${ }^{89}$ Roe, ibid.; Peck, Mokal and Janger, 'Financial Engineering' (n 8), 12.

90 Roe, Derivatives Market Payment Priorities, 567-568.

${ }^{11}$ See Baird, Bankruptcy's Uncontested Axioms, 589.

92 See, in particular, efforts to strengthen due diligence regarding counterparties instead of exclusive reliance on credit ratings Financial Stability Board, 'Principles for Reducing Reliance on Credit Ratings' (27.10.2010) $<$ http://www.financialstabilityboard.org/wpcontent/uploads/r_101027.pdf?page_moved=1> accessed 10 March 2015.

93 See, e.g., AG Haldane and RM May, 'Systemic Risk in Banking Ecosystems' (2011) 469 Nature $351-$ 355

94 See, e.g., Financial Stability Board, Principles for Sound Compensation Practices (2.4.2009) $<$ http://www.financialstabilityboard.org/wp-content/uploads/r_0904b.pdf $>$; Principles for an Effective
} 
directly, instead of using the threat of unenforceability, the consequences of which are difficult to contain, as a vehicle. They are currently being refined and implemented on a wide scale, but of course this does not per se exclude complementary adjustments to the safe harbour regime should they prove necessary.

\section{COLLATERAL/LIQUIDITY SHORTAGES}

When a financial institution enters troubled waters, the safe harbour-protected liquidation rights of counterparties will be triggered at some point. The contractual arrangements with basically all counterparties are highly likely to be affected simultaneously. ${ }^{95}$ Such a scenario of mass liquidation can have adverse systemic effects that antagonise the beneficial systemic effects of safe harbours. ${ }^{96}$ The two following examples illustrate how safe harbour rules can limit and spread contagion at the same time - 'which effect is more important is conceptually indeterminate', thereby weakening the systemic risk rationale for insolvency safe harbours. ${ }^{97}$

A first example 98 of off-setting systemic benefits and drawback relates to a phenomenon that was a major transmission mechanism for systemic risk during the recent financial crisis. The failure of a major participant in the highly concentrated derivatives market causes a liquidity and collateral shortage. Safe harbours, on the one hand, protect the market from these failures because the relevant counterparties can have recourse to close-out netting and seize collateral. Thus, the failure of a major player is unlikely immediately to cause further insolvencies through the domino effect. However, all the insolvent's counterparties would need to replace all terminated contracts in order to re-hedge their open positions, i.e., a large number of new contracts would be created elsewhere in the market within a very short time frame. Fire-sale liquidation of collateral and the sale of further assets to be able to post cash collateral under the

Risk Appetite Framework, (18.11.2013) < $\quad$ http://www.financialstabilityboard.org/wpcontent/uploads/r_131118.pdf >; Progress and Next Steps towards Ending To-Big-To-Fail (2.9.2013) $<$ http://www.financialstabilityboard.org/wp-content/uploads/r_130902.pdf $>$. All URLs accessed 10 March 2015. Many, if not most, post-crisis legislative initiatives address moral hazard and to-big-to-fail in one way or the other.

95 See, e.g., Section 5(a)(vi) ISDA master agreement, the 'cross-default' provision following which a default event will occur if a party defaults on a third-party obligation and the default or the obligation is in excess of a specified threshold amount.

${ }_{96}$ Basel Committee on Banking Supervision, (n 69) para 115; Financial Stability Board, Key Attributes of Effective Resolution Regimes for Financial Institutions (2014), paragraphs 4.3-4.4 and Annex IV; See Bliss and Kaufman, Derivatives and Systemic Risk, 20; Duffie and Skeel, 'Cost and Benefits of Automatic Stays' (n 13) 10.

${ }^{97}$ Roe, Derivatives Market Payment Priorities, 566-567. See Edwards and Morrison, Derivatives and the Bankruptcy Code, 2.

98 See Bliss and Kaufman, Derivatives and Systemic Risk, 11, 18-19 and fig. 2; Edwards and Morrison, Derivatives and the Bankruptcy Code, 10-11; Morrison, Roe and Sontchi, Rolling Back the Repo Safe Harbors, 14-16; Roe, Derivatives Market Payment Priorities, 545-546 (n 12). 
new contracts might considerably depress asset prices and might still push the entire market into a collateral crunch.

A second example ${ }^{99}$ relates to the situation of financial institutions that are already ailing but not yet technically insolvent, or in relation to which no proceedings have been opened yet. Does the protection of close-out netting and collateral arrangements exacerbate or improve their financial position? On the one hand, if parties are properly collateralised, close-out netting and collateral arrangements ensure that a market participant is able to continue trading, since as long as there is no actual failure (or other termination event), its counterparties will see no immediate need to pull out of the relationship. ${ }^{100}$ Thus close-out netting and collateral, at this stage, can help to prevent a further deterioration of the financial position of an ailing firm. On the other hand, it might be argued that as soon as the market becomes aware of financially deteriorating conditions, collateral arrangements will lead to calls for additional collateral, since the collateral taker will have initially contented itself with collateral the value of which was inferior to the actual exposure (which is common practice between financially healthy parties). This would force the ailing firm into a liquidation of assets in order to meet these demands and spark a depression in asset prices, as the valuation of assets is based on market price ('mark-to-market'), further aggravating the situation. The moment the firm failed to provide sufficient collateral to one of its many counterparties, thereby triggering close-out, cross-default clauses would ensure that virtually all contracts with other market participants were closed out at the same time, thus leaving the firm totally unhedged. Its financial position will prevent it from replacing these hedges at market price, a situation guaranteed to propel it over the brink of insolvency very quickly, rendering any further attempts at restoring viability useless.

This example points to the important issue of insufficient levels of initial collateralisation (generally called 'initial margin'), which has been an important crisis accelerator. Safe harbour regimes allow for adjusting or margining during the lifetime of the contract. As a consequence, parties often do accord not to provide collateral from the outset but do so only later, typically when the financial situation of one of them deteriorates. ${ }^{101}$ However, from the insolvency law perspective, the rational for this exceptions was to prevent unenforceability of collateral provided prior to insolvency, including collateral provided during a so-called suspect period, since, from the point of view of the estate, there is no need for avoidance. ${ }^{102}$ The background here is that margining requires such an exemption as otherwise there would always be a residual risk that margining could be avoided by the court, notably on grounds of preferential treatment of creditors. If applied consistently,

\footnotetext{
99 See Bliss and Kaufman, Derivatives and Systemic Risk, 10, 19. Roe, 'Derivatives Market Payment Priorities', 565-566; see also Edwards and Morrison 2005, 91, 94, 101 (citing the example of the failure of Long Term Capital Management (LTCM) in 1998).

100 See Morrison, Roe and Sontchi, 'Rolling Back the Repo Safe Harbors', 9 (n 12).

101 See FSB, 'Implementing OTC Derivatives Market Reform' (2010) para 3.6.2 $<$ http://www.financialstabilityboard.org/wp-content/uploads/r_101025.pdf> accessed 22 March 2015.

102 See Recital 16 Financial Collateral Directive.
} 
margining does not actually constitute preferential treatment. Other creditors are not disadvantaged because there is no net outflow of assets from the pool. However, safe harbour rules in many jurisdictions do not distinguish on the basis of the criterion of net outflow but restrict avoidance more generally. ${ }^{103}$ As a consequence, later delivery of collateral is not voidable even in cases in which there is a net outflow of assets. In practice, parties use this freedom in 'good times' to suspend the provision of initial margin for an indeterminate period, notably as long as the obligor is financially healthy. ${ }^{104}$ Yet this practice probably offends against the rationale for safe harbours, as collateral posted on these grounds within the 'suspect period' before insolvency could be regarded as a preference in that it does not merely reflects an increased obligation. ${ }^{105}$ It is also problematic in terms of systemic risk, as it does not require a great flight of the imagination to see that not enough collateral would be available should calls for additional collateral occur on a wider scale across the market, which is exactly the mechanism that caused the insolvency of AIG during the financial crisis. Any defaults on calls for additional collateral would trigger liquidation under the relevant master agreements. Thus, insufficient initial margin, to the extent made possible by the insolvency safe harbours, would appear to be a significant crisis accelerator. However, again, this problem could potentially be addressed from different angles. The insolvency safe harbours could either be narrowed so that calls for additional margin that went beyond a mere adjustment of values could be avoided, or regulation could impose proper collateralisation on the parties. After the crisis, the international community went for the second option by setting standards on initial margin while at the same time upholding the safe harbours in this respect. 106 These standards pay particular attention to the equilibrium of systemic risk on the one hand and liquidity on the other hand, notably by imposing gradual requirements that are also phased in over a longer period. This measure is complimentary to other regulatory rules, such as transparency requirements regarding repo portfolios, restrictions on re-use of collateral securities, mandatory haircuts ${ }^{107}$, liquidity buffers and requirements for

\footnotetext{
103 See, in particular, Recital 16 Financial Collateral Directive: '[...] The intention [of restricting avoidance] is merely that the provision of top-up or substitution financial collateral cannot be questioned on the sole basis that the relevant financial obligations existed before that financial collateral was provided, or that the financial collateral was provided during a prescribed period. [...]' (emphasis added).

104 Roe, 'Derivatives Market Payment Priorities' (n 13) 563.

105 Roe, ibid., 573; Mooney, 'The Bankruptcy Code's Safe Harbors' (n 9), 257; Skeel and Jackson, 'Transaction Consistency' (n 13) 190-191.

106 Basel Committee on Banking Supervision and Board of the International Organisation of Securities Commissions, 'Margin requirements for non-centrally cleared derivatives' (March 2015) $<$ http://www.bis.org/bcbs/publ/d317.htm> accessed 17 March 2015; IOSCO Committee on Payment and Settlement Systems, 'Principles for Financial Market Infrastructures' (April 2012) Principle 6 http://www.bis.org/cpmi/publ/d101a.pdf; Regulation (EU) No 648/2012 of the European Parliament and of the Council of 4 July 2012 on OTC derivatives, central counterparties and trade repositories (commonly called 'EMIR') Article 46(1).

107 'Haircut' is market vernacular for a risk control measure applied to underlying assets whereby the value of those underlying assets is calculated as their market value reduced by a certain percentage (the 'haircut'). Haircuts are applied by a collateral taker in order to protect itself from losses resulting from declines in the market value of the collateral asset in the event that it needs to liquidate that collateral, see
} 
central clearing and reporting of derivatives. ${ }^{108}$ All these measures are conceived to directly address the systemic risk flowing from the use of repos and securities lending transactions and derivatives, amongst other purposes. It would not be possible to achieve similarly well-calibrated solutions to that problem by abolishing or restricting safe harbour regimes — such an approach would be too bold and the resulting legal uncertainty would paralyse the market as nobody could rely on enforceability of contractual risk mitigation.

\section{BANK RESOLUTION AND SYSTEMIC RELEVANCE ${ }^{109}$}

As discussed before, one of the rationales of safe harbours is the need to prevent the systemic consequences of the failure of financial institutions. Obviously, not every failure need trigger systemic risk: for instance, the breakdown of a local savings bank will leave the wider financial world and economy largely unaffected. Typically, the systemic importance of financial institutions grows with increasing size, irreplaceability and interconnectedness. ${ }^{110}$ Therefore, safe harbours have the most effect where they protect large, interconnected institutions from the insolvency of their peers. However, it now appears that this understanding should be fundamentally revised, as the largest financial institutions will, in future, no longer enter into insolvency proceedings but instead will face 'resolution'. Supervisory authorities will now in practice use this new, special administrative procedure to stave off consequences of the kind experienced in the wake of the Lehman failure, deploying various tools such as transferring viable business to a state-owned bridge bank or a healthy other bank, or converting debt owed by the failing bank into shares of it ('bail-in'). Resolution regimes are now being

\footnotetext{
European Central Bank online glossary,

<https://www.ecb.europa.eu/home/glossary/html/glossh.en.html> accessed 10 March 2015.

'Mandatory haircut' refers to a legal requirement to apply such abatement for risk management purposes, see Basel Committee on Banking Supervision and Board of the International Organisation of Securities Commissions, 'Margin requirements for non-centrally cleared derivatives' (March 2015) $<$ http://www.bis.org/bcbs/publ/d317.htm $>$ accessed 17 March 2015. Also cf the meaning of 'mandatory haircut' outside the financial context <http://www.huffingtonpost.co.uk/2014/03/26/north-korea-kim-jong-un-hair_n_5033929.html> accessed 10 March 2015.

108 See, in particular, European Commission, Proposal for a Regulation of the European Parliament and of the Council on reporting and transparency of securities financing transactions (29.01.2014) $\operatorname{COM}(2014) 40$ final < http://ec.europa.eu/transparency/regdoc/rep/1/2014/EN/1-2014-40-EN-F11.Pdf $>$ accessed 9 April 2015; FSB, Strengthening Oversight and Regulation of Shadow Banking, (29.8.2013) <http://www.financialstabilityboard.org/wp-content/uploads/r_130829a.pdf>; Regulatory Framework for Haircuts on non-centrally cleared securities Financing Transactions (14.10.2014) http://www.financialstabilityboard.org/wp-content/uploads/r_141013a.pdf as well as the measures listed in $\mathrm{n} 106$.

109 I am grateful to Johannes Rehahn, research assistant at the LSE Law Department, for his valuable assistance on this section.

110 International Monetary Fund/Bank for International Settlements/Financial Stability Board, Guidance to Assess the Systemic Importance of Financial Institutions, Markets and Instruments: Initial Considerations (2009) paras 12-15 < http://www.bis.org/publ/othp07.pdf> accessed 10 March 2015.
} 
introduced globally ${ }^{111}$ and apply to banks, investment firms, ${ }^{112}$ and, increasingly, financial market infrastructures, ${ }^{113}$ the three most important categories of financial institution in systemic terms. Insolvency of systemically important financial institutions will therefore be a well-nigh redundant concept. There will be no insolvency official or court involved and cherry-picking and avoidance for preference will not be available. Insolvency safe harbours will therefore remain relevant only to the counterparties of failing financial institutions other than banks, investment firms and financial market infrastructures.

Even where master agreements provide for termination and close-out upon reorganisation or restructuring, ${ }^{114}$ resolution regimes eschew the route of privileged treatment through a safe harbour-like mechanism. Instead, they espouse the idea of a stay or moratorium with automatic effect or one which may, and probably as a rule will, be imposed on the counterparties of the institution under resolution by regulators. ${ }^{115}$ This breathing space was introduced to allow the competent authority to evaluate the financial contracts of an ailing institution and to decide which should be transferred to a healthy institutions and which should remain in the ailing estate and be wound up. The idea is also to avoid important changes on the balance sheet caused by extensive exercise of termination rights. ${ }^{116}$ Resolution regimes are more clear-cut in this regard than insolvency laws. There are no exceptions from the administrative stay comparable to safe harbour rules in

\footnotetext{
111 The US introduced this mechanism in the Federal Deposit Insurance Act in 1991 to address negative externalities potentially caused by the exercise of termination rights. The FDIA was originally applicable to institutions with a banking licence. After the Financial Crisis, the US modelled a broader rule on the FDIA that was included in the Dodd-Frank Act, sections 201(a)(11), 203, now also covering bank holding companies and, under certain conditions, non-banks. England and Germany adopted similar rules in 2009 and 2010. Also in 2010, the mechanism was elevated to global best practice by the FSB and several jurisdictions have since followed suit. In 2011, the FSB published twelve main features of effective resolution regimes which were updated in October 2014; see Financial Stability Board, Key Attributes of Effective Resolution Regimes for Financial Institutions (2014)

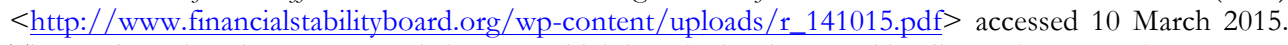
The EU introduced a common rule in 2014 which is to be implemented in all Member States by 2015; see Directive 2014/59/EU of the European Parliament and of the Council of 15 May 2014 establishing a framework for the recovery and resolution of credit institutions and investment firms and amending Council Directive 82/891/EEC, and Directives 2001/24/EC, 2002/47/EC, 2004/25/EC, 2005/56/EC, 2007/36/EC, 2011/35/EU, 2012/30/EU and 2013/36/EU, and Regulations (EU) No 1093/2010 and (EU) No 648/2012, of the European Parliament and of the Council [2014] OJ L173/190.

112 See article 1(1)(a) BRRD; sections 201(a)(7), (8), (11), 203(b) Dodd-Frank Act.

113 Committee on Payments and Market Infrastructures/International Organization of Securities Commissions, Recovery of Financial Market Infrastructures (2014) para 2.2.3 $<$ http://www.iosco.org/library/pubdocs/pdf/IOSCOPD455.pdf $>$ accessed 10 March 2015; Financial Stability Board ( $\mathrm{n}$ 94) para 1.2. In the EU, the Consultation on a framework for the recovery and resolution of financial institutions other than banks was closed on 28 December 2012. No further steps have been taken so far. Under US law, large parts of the financial market infrastructure are already covered; see sections 201(a)(8), (11), (14), 102(a)(4)(C) Dodd-Frank Act.

114 See, for example, sections 10(a)(vi), (b)-(g), 2(a)(v) of the 2011 Global Master Repurchase Agreement; section 5(a)(vii) ISDA 2002 Master Agreement: 'a general assignment, arrangement or composition with or for the benefit of its creditors' is assigned to be an Event of Default and Termination Event.

115 Articles 69-71 BRRD; section 210(c)(10)(B) Dodd-Frank Act.

116 Recital (94) BRRD.
} 
insolvency law. ${ }^{117}$ Indeed, the stay typically ends after two days and termination rights do not re-emerge in relation to those parts of the business saved by the regulator, in particular by transferring them to a financially healthy institution such as another bank. Termination rights are only revived in respect of those contracts which remain in the now isolated 'toxic' part of the estate which is destined to be liquidated by recourse to ordinary liquidation proceedings. ${ }^{118}$ But this rump estate would typically not be of systemic importance.

However, if systemic risk is increasingly brought under control by regulatory changes, 'what then remains of the original rationale for the safe harbours'?119 As a consequence of the introduction of resolution regimes, counterparties of an ailing financial institution will fall into one of the following three categories. Firstly, they will include those market participants that are not covered by safe harbour rules; these will generally belong to the non-financial world and will not be of systemic importance to the financial sector. Secondly, they will encompass those financial market participants generally covered to the extent that they deal with banks, investment firms and financial market infrastructures, which will in practice never become insolvent but enter resolution proceedings as they fail. Thirdly, they will include those financial market participants that are generally covered to the extent that they contract with a counterparty that enters insolvency proceedings as it fails, which means any financial institution other than banks, investment firms and financial market infrastructures or one of the aforementioned where the regulator decides not to invoke resolution but to allow the market participant to fail as it is of no systemic importance.

As a result, the safe harbour rules will remain without effect in the most systemically relevant failures, notably those of systemically relevant banks, investment firms and infrastructures. Instead, regulators will use a completely different set of legal mechanisms to avoid contagion, including a stay on termination of contracts. Where insolvency proceedings may still occur, notably upon failure of a systemically irrelevant financial institution, the systemic risk rationale of safe harbours does not bite: the failure of such an institution is unlikely to contribute significantly to systemic risk, either through knock-on effects on counterparties or by leading to a liquidity crunch. ${ }^{120}$ Thus, it is probably fair to state that the introduction of bank resolution regimes has considerably reduced the scope of application of safe harbours mainly to systemically irrelevant scenarios. This does however not remove the importance of safe harbours for all types of financial institution which occur before resolution or insolvency proceedings are opened, as described earlier.

\footnotetext{
117 However, title transfer financial collateral arrangements and set-off and netting arrangements shall be protected against split-up in the event of a transfer; see article 77 BRRD.

118 Articles 71(1)-(5), 118 BRRD. The suspension does not, however, apply where the counterparty is a central bank, a central counterparty or a settlement system, ibid (3); section 210(c)(8)(A) and (10)(B) Dodd-Frank Act.

119 Morrison, Roe and Sontchi, 'Rolling Back the Repo Safe Harbors', 3.

${ }^{120}$ Bliss and Kaufman, Derivatives and Systemic Risk, 17.
} 


\section{CONCLUSION}

Insolvency safe harbours are conceived on the basis of a double rationale. On the one hand, safe harbours allow for exponentially increased market liquidity based on the highly efficient use of assets for purposes of collateralisation. Literally any type of asset, regardless of its legal nature, can now be turned into cash using repo or derivatives transactions. Differences between cash, claims and securities become irrelevant and the importance of the legal nature of rights in these assets (traditionally full title, security interest or claim) equally vanishes. As a consequence, the concept of 'asset' assimilates with the concept of 'liquidity' as all positions held by a financial institution with its counterparty form part of the same gigantic current account- the grand total of which, the 'net amount', corresponds to the risk exposure. The amount of liquidity created through safe harbours, which mirrors the degree to which risk is shifted, depends on the scope of safe harbours (which types of transaction? Which types of financial institution?) as chosen by the relevant legislator.

On the other hand, insolvency safe harbours limit — or even well-nigh eliminate - individual counterparty credit risk for the sake of increased overall systemic stability. However, the systemic risk aspect of the rationale is much more complex than commonly understood and goes far beyond the idea that dominolike contagion is avoided from the outset because the counterparties of the insolvent party will not fail as a consequence of the safe harbour protection. Rather, that — valid — argument is at the same time supported and countered by other mechanisms that either limit (e.g., avoidance of runs on ailing firms) or increase (e.g., moral hazard) the systemic risk. Which of these effects will prevail depends on the concrete circumstances and is difficult to predict. The systemic risk rationale is further weakened by the appearance of bank resolution regimes. These new administrative procedures render safe harbours largely irrelevant as tools to mitigate systemic risk.

Furthermore, both the liquidity and the risk rationale are closely intertwined. The highly efficient use of homogenised assets on a cross-border, globalised basis makes collateral more readily available and at lower cost, but at the same time spreads the collateral cover very thinly over the market: it is large and flexible but can break easily if something goes wrong. So again, what is beneficial generally (collateral more easily available) may turn out to be dangerous in times of stress (no asset reserves).

The above leaves the legislator with a picture in which the containment of counterparty risk through safe harbours is clear, but where it is not so obvious whether the limitation of systemic risk is a good enough policy argument. This dilemma reflects the fact that in the financial market risk can be dispersed but will not effectively disappear until obligations are settled. Yet legislators, in their 
normative decisions, opt for liquidity and strong growth of the financial market an argument well-known in the world of traditional security interests, which generally privileges major market players for the sake of a more liquid lending market. To the extent that safe harbours are based on a systemic risk rationale, this is at odds with reality - the main argument, at least today, is liquidity. This incongruence explains why the debate on safe harbours is so relevant to the US but much less so in other jurisdictions. Where insolvency law is more creditorfriendly from the outset, liquidity of assets is a more attractive argument than it is in debtor-focused insolvency regimes.

Still, repealing or fundamentally revising the concept of safe harbours with a view to avoiding adverse systemic effects is not only unnecessary but rather counter-productive. ${ }^{121}$ First, systemic risk is based on an amalgam of many different causes and incentives and changing the safe harbour regime would only address one isolated aspect, whereas the overall repercussions on risk management flowing from changes to the safe harbour regime are potentially negative. Secondly, insolvency law, though it has significant influence on market participants' behaviour towards risk-taking while they are going concerns is too bold a tool to control that behaviour. This role is better vested in regulation. Regulation is able to address the vast majority of adverse systemic effects in which safe harbours may have a (smaller or larger) share, notably by establishing requirements for liquidity buffers, mandatory haircuts, initial margin requirements, central clearing etc., and in respect of risk-taking behaviour in a more selective way, without choking the liquidity made possible by the safe harbours.

Furthermore, there is no equally effective risk mitigation tool at hand at the moment, especially not from a global point of view. Only safe harbours allow for cross-jurisdictional use of assets on the present scale, an effect that is achieved through homogenous insolvency regimes in this respect. This globalisation of asset use could never be achieved on the basis of traditional security, if only for reasons of lack of legal certainty.

In the future, safe harbours will continue to spread to other jurisdictions. Insolvency safe harbours have a logical attraction for every aspiring financial market. The fact that safe harbours are an integral part of the capital requirements regime and the considerably increased liquidity that comes with safe harbours would make it virtually impossible for a jurisdiction to participate in the global financial market if they did not have a safe harbour regime. Contracting with market players from markets that lack safe-harbour protection is expensive and much riskier. Therefore, markets and regulators will need to continue implementing safe harbours, many using the Financial Collateral Directive of the UNIDROIT Principles on Close-out Netting as blueprints. As long as fundamental ideas about the size of the financial market and the acceptance of the

121 The recent report of the American Bankruptcy Institute on a possible reform of Chapter 11 (n 11) has stopped short of recommending a fundamental overhaul of the safe harbour concept. See, in particular, ibid. 102 in relation to the risk-accelerating effect of safe harbours. 
risk naturally flowing from it are not re-thought, there is no viable alternative to insolvency safe harbours. 